medRxiv preprint doi: https://doi.org/10.1101/2021.02.16.21251804; this version posted February 23, 2021. The copyright holder for this preprint (which was not certified by peer review) is the author/funder, who has granted medRxiv a license to display the preprint in perpetuity. It is made available under a CC-BY-NC-ND 4.0 International license .

\title{
Plasma Hydrogen Sulfide Production Capacity is Positively Associated with Post-Operative Survival in Patients Undergoing Surgical Revascularization
}

Alban Longchamp ${ }^{1,2, \star}$, Michael R. MacArthur ${ }^{3, *}$, Kaspar Trocha ${ }^{4}$, Janine Ganahl ${ }^{5}$, Charlotte G. Mann ${ }^{3}$, Peter Kip ${ }^{4}$, William W. King ${ }^{4}$, Gaurav Sharma ${ }^{4}$, Ming Tao ${ }^{4}$, Sarah J. Mitchell ${ }^{3}$, Tamás Ditrói ${ }^{6}$, Péter Nagy $^{6,7}$, C. Keith Ozaki ${ }^{4}$, Christopher Hine ${ }^{8}$, James R. Mitchell ${ }^{3}$

${ }^{1}$ Department of Vascular Surgery, Centre Hospitalier Universitaire Vaudois and University of Lausanne, Switzerland

${ }^{2}$ Department of Biomedical Sciences, University of Lausanne, Switzerland

${ }^{3}$ Department of Health Sciences and Technology, ETH Zurich, Switzerland

${ }^{4}$ Department of Surgery and the Heart and Vascular Center, Brigham \& Women's Hospital and Harvard Medical School, Boston, MA, USA

${ }^{5}$ Department of Molecular Metabolism, Harvard T. H. Chan School of Public Health, Boston, MA, USA

${ }^{6}$ Department of Molecular Immunology and Toxicology, National Institute of Oncology, Budapest, Hungary

${ }^{7}$ Department of Anatomy and Histology, University of Veterinary Medicine, Budapest, Hungary ${ }^{8}$ Department of Cardiovascular and Metabolic Sciences, Cleveland Clinic Lerner Research Institute, Cleveland, $\mathrm{OH}, \mathrm{USA}$

${ }^{*}$ Contributed equally

\#Correspondence to: alban.longchamp@chuv.ch

Department of vascular surgery, CHUV

Rue du Bugnon 46, 1011 Lausanne, Switzerland

Tel: 00415565510 
medRxiv preprint doi: https://doi.org/10.1101/2021.02.16.21251804; this version posted February 23, 2021. The copyright holder for this preprint (which was not certified by peer review) is the author/funder, who has granted medRxiv a license to display the preprint in perpetuity.

It is made available under a CC-BY-NC-ND 4.0 International license .

\section{ABSTRACT}

\section{Objective:}

Hydrogen sulfide $\left(\mathrm{H}_{2} \mathrm{~S}\right)$ is a gaseous signaling molecule and redox factor important for cardiovascular function. Deficiencies in its production or bioavailability are implicated in atherosclerotic disease.

However, it is unknown if circulating $\mathrm{H}_{2} \mathrm{~S}$ levels differ between vasculopaths and healthy individuals, and if so, whether $\mathrm{H}_{2} \mathrm{~S}$ measurements can be used to predict surgical outcomes. Here, we examine: 1) Plasma $\mathrm{H}_{2} \mathrm{~S}$ levels in patients undergoing vascular surgery and compare these to healthy controls, and 2) Associations between $\mathrm{H}_{2} \mathrm{~S}$ levels and mortality in surgical revascularization patients.

\section{Approach \& Results:}

Patients undergoing carotid endarterectomy, open lower extremity revascularization or leg amputation were enrolled. Peripheral blood was also collected from a matched cohort of 20 patients without peripheral or coronary artery disease. Plasma $\mathrm{H}_{2} \mathrm{~S}$ production capacity and sulfide concentration were measured using the lead acetate and monobromobimane methods, respectively. Plasma $\mathrm{H}_{2} \mathrm{~S}$ production capacity and plasma sulfide concentrations were reduced in patients with $P A D(p<0.001$, $p=0.013$ respectively). Patients that underwent surgical revascularization were divided into high versus low $\mathrm{H}_{2} \mathrm{~S}$ production capacity groups by median split. Patients in the low $\mathrm{H}_{2} \mathrm{~S}$ production group had increased probability of mortality $(p=0.003)$. This association was robust to correction for potentially confounding variables using Cox proportional hazard models.

\section{Conclusions:}

Circulating $\mathrm{H}_{2} \mathrm{~S}$ levels were lower in patients with atherosclerotic disease. Patients undergoing surgical revascularization with lower $\mathrm{H}_{2} \mathrm{~S}$ production capacity, but not sulfide concentrations, had increased probability of mortality within 36 months post-surgery. This work provides insight on the role $\mathrm{H}_{2} \mathrm{~S}$ plays as a diagnostic and potential therapeutic for cardiovascular disease. 
medRxiv preprint doi: https://doi.org/10.1101/2021.02.16.21251804; this version posted February 23, 2021. The copyright holder for this preprint

(which was not certified by peer review) is the author/funder, who has granted medRxiv a license to display the preprint in perpetuity.

It is made available under a CC-BY-NC-ND 4.0 International license .

\section{HIGHLIGHTS}

- Vascular disease patients have higher plasma hydrogen sulfide levels than controls without vascular disease as measured by two distinct methods, the lead acetate hydrogen sulfide release method and the HPLC-based monobromobimane method.

- Only the lead acetate hydrogen sulfide release method robustly predicts survival after vascular surgery intervention over 35 months of follow up.

- The lead acetate release method measures non-enzymatic hydrogen sulfide release from plasma which requires iron and is catalyzed by vitamin $B_{6}$.

\section{NONSTANDARD ABREVIATIONS AND ACRONYMS}

CARS2 Cysteinyl t-RNA synthetase

CBS Cystathionine-beta-synthase

CEA Carotid endarterectomy

CGL Cystathionine-gamma-lyase

CLI Critical limb ischemia

$\mathbf{H}_{2} \mathbf{S}$ Hydrogen sulfide

MI Myocardial infarction

MBB Monobromobimane

PAD Peripheral arterial disease

PLP Pyridoxal-5- phosphate 
medRxiv preprint doi: https://doi.org/10.1101/2021.02.16.21251804; this version posted February 23, 2021. The copyright holder for this preprint (which was not certified by peer review) is the author/funder, who has granted medRxiv a license to display the preprint in perpetuity.

It is made available under a CC-BY-NC-ND 4.0 International license .

\section{INTRODUCTION}

Hydrogen sulfide $\left(\mathrm{H}_{2} \mathrm{~S}\right)$ is a redox modifying and diffusible gasotransmitter that plays numerous physiologic roles across various organ systems including the cardiovascular system ${ }^{1}$. While high levels of exogenous $\mathrm{H}_{2} \mathrm{~S}$ are toxic, increased levels within a supraphysiologic range have been shown to mediate many beneficial effects ranging from stress resistance to longevity ${ }^{2-4}$. $\mathrm{H}_{2} \mathrm{~S}$ has also emerged as a critical mediator of vascular homeostasis ${ }^{5}$ through its functions as a vasodilator ${ }^{6}$, antioxidant ${ }^{7}$, oxygen sensor ${ }^{8,9}$, immunomodulator ${ }^{10}$, and anti-inflammatory gas ${ }^{11}$. Importantly, as atherosclerosis is a chronic inflammatory disease, it is important to note $\mathrm{H}_{2} \mathrm{~S}$ is shown to regulate several atherosclerotic cellular and inflammatory processes ${ }^{12-15}$.

While $\mathrm{H}_{2} \mathrm{~S}$ has been implicated in the pathogenesis of multiple cardiovascular disease processes, the measurement of $\mathrm{H}_{2} \mathrm{~S}$ is arduous and often relies on indirect measures and surrogates ${ }^{16-}$ 21. Nevertheless, characterizing the role of $\mathrm{H}_{2} \mathrm{~S}$ in systemic disease states such as peripheral arterial disease (PAD) may yield important insights on potential diagnostic and therapeutic applications.

We therefore assessed $\mathrm{H}_{2} \mathrm{~S}$ levels in human plasma using two measurement methods; the lead acetate $\mathrm{H}_{2} \mathrm{~S}$ production capacity quantification method and the monobromobimane method (MBB method) for sulfide quantification. Patients included in this study were diagnosed with either carotid artery stenosis requiring carotid endarterectomy (CEA), or peripheral artery disease (PAD) necessitating revascularization or amputation secondary to unsalvageable critical limb ischemia. Patients were prospectively followed for 36 months post-surgery with clinical outcomes and mortality measured. A baseline control cohort of patients matched for age, sex, and hypertension ${ }^{6}$, but with no histories of PAD, prior MI, coronary interventions, heart failure, or stroke were included for comparing $\mathrm{H}_{2} \mathrm{~S}$ levels in the diseased versus healthy state. Our study provides new insight into the relevance of circulating $\mathrm{H}_{2} \mathrm{~S}$ levels in patients suffering from atherosclerosis, and during surgical revascularization.

\section{MATERIAL AND METHODS}

\section{Study Design \& Demographic Data Collection}

Patients at a single institution undergoing elective vascular surgery including patients scheduled for carotid endarterectomy, open lower extremity revascularization, and major lower extremity amputation were enrolled. Informed consent was obtained for prospective collection of demographic and clinical data under a Partners Human Research Committee institutional review board approved protocol.

Surgical patients enrolled encompassed patients with carotid artery stenosis requiring CEA for asymptomatic ( $>80 \%$ stenosis) or symptomatic ( $>50 \%$ stenosis) carotid disease, patients with PAD requiring infra-inguinal surgical revascularization and patients with secondary critical limb ischemia 
medRxiv preprint doi: https://doi.org/10.1101/2021.02.16.21251804; this version posted February 23, 2021. The copyright holder for this preprint (which was not certified by peer review) is the author/funder, who has granted medRxiv a license to display the preprint in perpetuity.

It is made available under a CC-BY-NC-ND 4.0 International license .

(CLI) refractory to lifestyle and surgical interventions requiring major lower extremity amputation (above knee or below knee amputation).

Baseline patient risk factors and demographics were collected including age, race, history of PAD, history of stroke or myocardial infarction as well as history of coronary intervention

(Supplemental Table 1). To compare levels of $\mathrm{H}_{2} \mathrm{~S}$ between patients with vascular disease vs. healthy patients, a group of 20 control subjects were enrolled without documented or diagnosed PAD or CAD. This control cohort were matched for age, sex and hypertension. Patients were excluded if they were $<18$ years, had an emergent indication for the operation or if they were involved in another clinical research study.

\section{Hydrogen Sulfide Measurements}

On the day of surgery, but prior to surgical intervention, peripheral venous blood was collected into ethylenediaminetetraacetic acid (EDTA) collection tubes at the time of peripheral intravenous line placement. The tube was inverted several times to ensure mixing with the anticoagulant and then transferred to the lab for processing. To obtain plasma all samples were centrifuged at room temperature for 15 minutes at $2,000 \mathrm{~g}$, plasma was then stored at $-80^{\circ} \mathrm{C}$ for future analysis. All samples were then thawed and processed for $\mathrm{H}_{2} \mathrm{~S}$ production capacity at once to ensure uniformity.

Hydrogen sulfide production capacity was measured using the lead acetate method ${ }^{22}$. In brief, plasma was mixed with 150ul freshly prepared reaction mixture, containing $100 \mathrm{mM}$ L-cysteine and 0.5 mM PLP in Phosphate buffered saline (PBS) in a plastic 96-well plate. The plate was then incubated at $37^{\circ} \mathrm{C}$ with lead acetate embedded filter paper on top. Upon the reaction of $\mathrm{H}_{2} \mathrm{~S}$ with the lead acetate paper, a dark lead sulfide precipitate is produced. The paper was incubated until a detectable, but nonsaturated signal was seen. The amount of lead sulfide captured on the paper was quantitated by measuring the integrated density of each well area using ImageJ software.

Hydrogen sulfide concentrations using the MBB method was conducted as described previously ${ }^{23}$. Briefly: In almost complete darkness due to the light sensitivity of the MBB reagent, $20 \mu \mathrm{l}$ of $50 \mathrm{mM}$ HEPES ( $\mathrm{pH}=8.0$ ) buffer and $20 \mu \mathrm{l}$ of $10 \mathrm{mM}$ monobromo-bimane (Sigma Aldrich) was added to $20 \mu$ of plasma sample. After 10 minutes in the dark at room temperature, the product sulfidedibimane was extracted with $200 \mu$ of pure ethyl acetate. The organic supernatant was collected and evaporated to dryness and stored at $-20^{\circ} \mathrm{C}$ until measurement. The solid samples were redissolved prior to HPLC measurements in acetonitrile. $10 \mu \mathrm{l}$ was injected and separated on an Agilent Eclipse

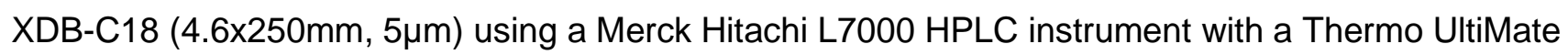
3000 fluorescent detector. The elution method employed a 28 min long gradient using water and acetonitrile both containing $0.1 \%$ TFA. The detection of the product was carried out using UV- 
medRxiv preprint doi: https://doi.org/10.1101/2021.02.16.21251804; this version posted February 23, 2021. The copyright holder for this preprint (which was not certified by peer review) is the author/funder, who has granted medRxiv a license to display the preprint in perpetuity. It is made available under a CC-BY-NC-ND 4.0 International license .

absorbance measurement at $254 \mathrm{~nm}$ and fluorescent measurement with extinction at $390 \mathrm{~nm}$ and detection at $480 \mathrm{~nm}$. Quantitation was done using a standard calibration curve in aqueous buffered solutions, where $\mathrm{H}_{2} \mathrm{~S}$ concentrations were verified by the DTNB assays. It should be noted that the MBB method measures endogenous sulfide levels that are easily liberated from the bound plasma sulfide pool and hence absolute values largely depend on the applied conditions (temperature, alkylation time, concentration conditions etc). This is the reason why absolute values should not be compared with values reported in other studies ${ }^{21}$.

The enzymatic activity of CBS in blood samples was measured by an HPLC-MS/MS protocol previously published ${ }^{24}$. Briefly, $20 \mu \mathrm{L}$ of plasma sample was added to $25 \mu \mathrm{L}$ of solution containing 200 $\mathrm{mmol} / \mathrm{L}$ Tris- $\mathrm{HCl}$ (pH 8.6), $1 \mathrm{mmol} / \mathrm{L}$ pyridoxal 5'-phosphate, $1 \mathrm{mmol} / \mathrm{L}$ SAM and $40 \mathrm{mmol} / \mathrm{L} \mathrm{2,3,3-2H-}$ labeled serine (Cambridge Isotope Laboratories, Inc). $5 \mu \mathrm{L}$ of starting solution containing $280 \mathrm{mmol} / \mathrm{L}$ homocysteine thiolactone in $100 \mathrm{mmol} / \mathrm{L}$ Tris- $\mathrm{HCl}(\mathrm{pH} 8.6), 10 \mathrm{mmol} / \mathrm{L}$ DTT, $1.225 \mathrm{~mol} / \mathrm{L} \mathrm{NaOH}$ was incubated for 5 minutes at $37^{\circ} \mathrm{C}$ to produce homocysteine by thiolactone cleavage, $\mathrm{pH}$ was adjusted to 8.6 with $1: 1 \mathrm{HCl}$ solution and the solution was added to the plasma mixture. After 4 hours of incubation at $37^{\circ} \mathrm{C}$, the reaction was quenched by acidification of the mixture with $100 \mu \mathrm{L}$ of EZ:faast Internal Standard Solution (Phenomenex) containing $3.3 \mu \mathrm{mol} / \mathrm{L}$ of internal standard 3,3,4,4-2H-labeled cystathionine. Sample preparation was carried out using EZ:faast kit (Phenomenex) kit, that included a solid phase extraction step, derivatization with propyl chloroformate, and an extraction into an organic solvent. The prepared samples were separated on an EZ:faast AAA-MS column $(250 \times 2.0 \mathrm{~mm}$, Phenomenex) using LC and MS settings described in the EZ:faast user manual using a Thermo Scientific UltiMate 3000 HPLC connected to a Thermo Scientific LTQ-XL MS instrument. Concentrations (and enzyme activities) were calculated using the internal standard.

\section{Statistics}

Plasma $\mathrm{H}_{2} \mathrm{~S}$ production capacity and sulfide concentration in vascular surgery patients and healthy controls were compared using Student's t test. Pearson correlation coefficient was calculated to assess the association between plasma $\mathrm{H}_{2} \mathrm{~S}$ production capacity and plasma sulfide concentration. The Kaplan-Meier method was used to estimate survival in high and low $\mathrm{H}_{2} \mathrm{~S}$ production capacity/free sulfide groups and groups were compared using log-rank test. Cox proportional hazard models were fit to estimate mortality hazard ratios between high and low $\mathrm{H}_{2} \mathrm{~S}$ producing groups, corrected for potentially confounding variables (age, gender, BMI). Both unadjusted and adjusted Cox proportional hazard models met assumptions of proportional hazard. To assess the odds of post-surgical complication in high vs low $\mathrm{H}_{2} \mathrm{~S}$ producing individuals, Fisher's exact test was used. Statistical tests were performed using Graphpad Prism 7 and R version 3.3.2. Kaplan-Meier curves and Cox proportional hazard models were fit in $\mathrm{R}$ using the Survival package and Kaplan-Meier curves were 
medRxiv preprint doi: https://doi.org/10.1101/2021.02.16.21251804; this version posted February 23, 2021. The copyright holder for this preprint (which was not certified by peer review) is the author/funder, who has granted medRxiv a license to display the preprint in perpetuity.

It is made available under a CC-BY-NC-ND 4.0 International license .

visualized using the Survminer package. All reported $P$ values are based on 2 -sided tests and $P$ values of less than 0.05 were considered statistically significant.

\section{RESULTS}

Results using the lead acetate-based $\mathrm{H}_{2} \mathrm{~S}$ production capacity assay showed that healthy controls had significantly higher $\mathrm{H}_{2} \mathrm{~S}$ production capacity compared to vascular disease patients (Fig1A, S1A, 64.4 \pm 5.1 vs $40.16 \pm 1.8$ arbitrary units, $p<0.001$ ). Results using the MBB method also showed that healthy controls had significantly greater plasma sulfide levels (Fig1B, $0.95 \pm 0.07$ vs $0.76 \pm 0.03 \mu \mathrm{M}, \mathrm{p}<0.05)$. Although both of these sulfide-based measurements were significantly higher in healthy controls, there was no observable correlation between the measurements $\left(\mathbf{F i g} 1 \mathbf{C}, r_{\mathrm{s}}=-0.12\right.$, $p=0.34)$, suggesting that the two methods measure fundamentally different phenomena.

To assess the associations of these $\mathrm{H}_{2} \mathrm{~S}$ measurements with clinical outcomes after surgical procedures, the vascular surgery patients were divided by median split into patients with high and low pre-operative $\mathrm{H}_{2} \mathrm{~S}$ production capacity (FigS1B). Over 36 months of follow up, patients with low $\mathrm{H}_{2} \mathrm{~S}$ production capacity had significantly decreased probability of survival compared to patients with high $\mathrm{H}_{2} \mathrm{~S}$ production capacity (Fig1D, $54 \%$ vs $82 \%$ survival probability, log-rank test $\mathrm{p}=0.0029$ ). However, when patients were divided by median split into high and low MBB-measured sulfide measurements, there was no significant association with survival and the trend was reversed such that those with higher sulfide tended to have lower probability of survival (Fig1E, $71 \%$ vs $52 \%$ survival probability, logrank test $=0.15$ ).

To further assess the robustness of $\mathrm{H}_{2} \mathrm{~S}$ production capacity as a predictor of mortality after a vascular surgery intervention, we generated Cox proportional hazard models to adjust for potential confounding variables. A univariate unadjusted model showed that individuals in the high $\mathrm{H}_{2} \mathrm{~S}$ production capacity group had significantly reduced risk of death during follow up $(\mathrm{HR}(95 \% \mathrm{Cl})=$ $0.31(0.11-0.87)$, coefficient $p=0.025$, model Wald $p=0.025)$. In a Cox proportional hazard model adjusted for age, BMI, gender, smoking history and race, $\mathrm{H}_{2} \mathrm{~S}$ production capacity was significantly associated with survival ( $\mathrm{HR}=0.94, \mathrm{Cl}=0.90-0.99$, coefficient $\mathrm{p}=0.017$, model Wald $\mathrm{p}=0.009$, Figure 2).

Finally, to characterize the biochemical nature of the plasma $\mathrm{H}_{2} \mathrm{~S}$ production capacity measurement, we investigated whether it might be generated by enzymatic or non-enzymatic production. It has been proposed that the $\mathrm{H}_{2} \mathrm{~S}$ generating enzyme cystathionine beta synthase (CBS) is present in plasma. We measured plasma CBS activities, but found no observable association between plasma CBS activity and $\mathrm{H}_{2} \mathrm{~S}$ production capacity (FigS1C, $r=-0.07, p=0.71$ ). We next performed the assay under denaturing conditions by including heating and adding DTT and found a highly correlated pattern of signals as when performed under non-denaturing conditions (FigS1D, $r=0.34, p=0.0002$ ). 
medRxiv preprint doi: https://doi.org/10.1101/2021.02.16.21251804; this version posted February 23, 2021. The copyright holder for this preprint (which was not certified by peer review) is the author/funder, who has granted medRxiv a license to display the preprint in perpetuity.

It is made available under a CC-BY-NC-ND 4.0 International license .

These results suggest $\mathrm{H}_{2} \mathrm{~S}$ production arising from a non-enzymatic process. Finally, we added chelators and found that EDTA was able to almost completely ablate the $\mathrm{H}_{2} \mathrm{~S}$ release, while EGTA was not (FigS1E). On the other hand, EDTA had a reverse effect on measured sulfide concentrations by the MBB method ${ }^{21}$ corroborating that the two methods measure sulfide released from fundamentally different endogenous pools. This suggests a vital role for iron as a catalyst of the measured $\mathrm{H}_{2} \mathrm{~S}$ release. These results on the probably non-enzymatic nature of the signal are in agreement with the recent thorough characterization of mechanisms of $\mathrm{H}_{2} \mathrm{~S}$ release in blood by Hine and colleagues ${ }^{25}$.

\section{DISCUSSION}

Pre-clinical studies have suggested that decreased levels of $\mathrm{H}_{2} \mathrm{~S}$ accelerate the development of atherosclerosis $^{12}$, and are reduced in the skeletal muscle of CLI patients ${ }^{1}$. Here we show that patients with vascular disease have significantly decreased circulating $\mathrm{H}_{2} \mathrm{~S}$ production capacity and sulfide concentrations, compared to subjects with no clinical evidence of coronary or peripheral artery disease. Together, these results suggest that patients with atherosclerotic vascular disease have a decreased capability to generate $\mathrm{H}_{2} \mathrm{~S}$. Furthermore, patients with higher $\mathrm{H}_{2} \mathrm{~S}$ production capacity measured prior to vascular surgery had reduced post-operative mortality at 36 months follow-up compared to those with lower $\mathrm{H}_{2} \mathrm{~S}$ production. Interestingly, this association was not observed with sulfide levels that were measured by the MBB-method. While this suggest that although both measures are related to sulfide release from bound sulfide reserves, they specifically capture distinct biological phenomena with clinical relevance. Endogenous enzymatic biosynthesis of $\mathrm{H}_{2} \mathrm{~S}$ in cells relies on three pyridoxal-5- phosphate (PLP) dependent enzymes responsible for the metabolism of the amino acid L-cysteine. These enzymes being cystathionine-gamma-lyase (CGL), cystathionine-beta-synthase $(C B S)^{26}$ and cysteinyl t-RNA synthetase (CARS2) ${ }^{27}$ as well as a non-PLP dependent enzyme, 3-mercaptopyruvate sulfurtransferase (3-MST) ${ }^{28}$ which are responsible for much $\mathrm{H}_{2} \mathrm{~S}$ production in numerous cell types including endothelial cells. Here we show that the clinically relevant $\mathrm{H}_{2} \mathrm{~S}$ production capacity measurement captures non-enzymatic $\mathrm{H}_{2} \mathrm{~S}$ production.

Hine and colleagues have recently performed a thorough chemical characterization of the mechanisms of non-enzymatic $\mathrm{H}_{2} \mathrm{~S}$ production in blood, demonstrating that it is catalyzed by iron and vitamin $\mathrm{B}_{6}(\mathrm{PLP})^{25}$. Although this work gives us many clues, important questions remain about what specific components of the plasma determine and regulate $\mathrm{H}_{2} \mathrm{~S}$ production capacity. One theory revolves around the sulfur containing amino acid homocysteine, which in itself has been long associated with cardiovascular disease risk, but its mechanism of pathology is not well understood ${ }^{29}$. Homocysteine has been reported to capture $\mathrm{H}_{2} \mathrm{~S}$ and/or $\mathrm{HS}^{-}$to form a homocysteine persulfide in cardiac tissue, which could potentially interfere with $\mathrm{H}_{2} \mathrm{~S}$-related cardiovascular protection ${ }^{30}$. Thus, if 
medRxiv preprint doi: https://doi.org/10.1101/2021.02.16.21251804; this version posted February 23, 2021. The copyright holder for this preprint (which was not certified by peer review) is the author/funder, who has granted medRxiv a license to display the preprint in perpetuity. It is made available under a CC-BY-NC-ND 4.0 International license .

surgical patients with decreased survival showed an increase in plasma homocysteine levels, then this could explain the dichotomy in $\mathrm{H}_{2} \mathrm{~S}$ release in these patients using the two different methods (lead acetate vs. MBB), as homocysteine can trap $\mathrm{H}_{2} \mathrm{~S}$ under non-denaturing conditions in the MBB method.

Furthermore, in the non-enzymatic production of $\mathrm{H}_{2} \mathrm{~S}$ in plasma catalyzed by iron described previously ${ }^{25}$ and confirmed here, PLP still acts as an important co-factor by the formation of a Schiff base and subsequent cysteine-aldimine and thiazolidine five-member ring intermediates prior to iron rapidly catalyzing the release of the sulfide. Importantly, homocysteine itself can also form a Schiff base with PLP, except it will result in a more thermodynamically stable six-member tetrahydrothiazine ring ${ }^{31}$. The formation of the stable tetrahydrothiazine ring poses two complications for $\mathrm{H}_{2} \mathrm{~S}$ production in circulation: the first being sequestration of valuable PLP co-factor from both enzymatic and nonenzymatic $\mathrm{H}_{2} \mathrm{~S}$ production where cysteine serves as substrate; and the second being slow $\mathrm{H}_{2} \mathrm{~S}$ production kinetics when iron serves as a catalyst ${ }^{25}$.

In addition to addressing the issues brought up in the discussion, the results reported here will aid in the development of specific $\mathrm{H}_{2} \mathrm{~S}$ assays for diagnostic purposes. Further, they will guide therapeutic interventions if these specific determinants are shown to be causal to the disease process. Despite these remaining questions, we demonstrate that the lead acetate assay represents a simple, rapid and very low-cost method which appears to capture substantial information on clinical risk in this population.

Limitations of our study include the quantification of $\mathrm{H}_{2} \mathrm{~S}$ using the lead acetate method measures only relative differences in $\mathrm{H}_{2} \mathrm{~S}$ between individuals and groups, and not absolute differences. Likewise, it primarily serves as a surrogate for the actual amount of $\mathrm{H}_{2} \mathrm{~S}$ produced from available substrates in plasma. It is also important to note that mortality outcomes in this study encompassed two uniquely different patient populations, patients with carotid stenosis and patients with PAD necessitating surgical revascularization or amputation. These differences may influence disparities in mortality outcomes and future work will need to validate these findings in larger cohorts with more homogenous interventions. Nevertheless, we highlight our important results showing that both $\mathrm{H}_{2} \mathrm{~S}$ production capacity and MBB-method-measured sulfide levels in vascular patients were significantly reduced compared to healthy subjects, indicating a potential correlation between $\mathrm{H}_{2} \mathrm{~S}$ and the progression of cardiovascular pathology. These results provide further insights into the role of $\mathrm{H}_{2} \mathrm{~S}$ biology in surgical patients and open an avenue for the use of $\mathrm{H}_{2} \mathrm{~S}$ for diagnostics and therapeutics in those with dysfunction of their vascular system. 
medRxiv preprint doi: https://doi.org/10.1101/2021.02.16.21251804; this version posted February 23, 2021. The copyright holder for this preprint

(which was not certified by peer review) is the author/funder, who has granted medRxiv a license to display the preprint in perpetuity.

It is made available under a CC-BY-NC-ND 4.0 International license .

\section{ACKNOWLEDGMENT}

Acknowledgments: none

Sources of Funding: The Swiss National Science Foundation (PZ00P3-185927) to A.L., and the National Institutes of Health (R01HL148352) to C.H. P.N. acknowledges financial support from the Hungarian Thematic Excellence Program TKP2020-NKA-26, KH_126766, K_129286 from the Hungarian National Research, Development and Innovation Office.

\section{Disclosures: none}

\section{REFERENCES}

1. Islam KN, Polhemus DJ, Donnarumma E, Brewster LP and Lefer DJ. Hydrogen Sulfide Levels and Nuclear Factor-Erythroid 2-Related Factor 2 (NRF2) Activity Are Attenuated in the Setting of Critical Limb Ischemia (CLI). Journal of the American Heart Association. 2015;4.

2. Hine C, Harputlugil E, Zhang Y, Ruckenstuhl C, Lee BC, Brace L, Longchamp A, TreviñoVillarreal JH, Mejia P, Ozaki CK, Wang R, Gladyshev VN, Madeo F, Mair WB and Mitchell JR.

Endogenous hydrogen sulfide production is essential for dietary restriction benefits. Cell. 2015;160:13244.

3. Kip P, Tao M, Trocha KM, MacArthur MR, Peters HAB, Mitchell SJ, Mann CG, Sluiter TJ, Jung J, Patterson S, Quax PHA, de Vries MR, Mitchell JR and Keith Ozaki C. Periprocedural Hydrogen Sulfide Therapy Improves Vascular Remodeling and Attenuates Vein Graft Disease. Journal of the American Heart Association. 2020;9:e016391.

4. $\quad$ Longchamp A, Mirabella T, Arduini A, MacArthur MR, Das A, Treviño-Villarreal JH, Hine C, BenSahra I, Knudsen NH, Brace LE, Reynolds J, Mejia P, Tao M, Sharma G, Wang R, Corpataux JM, Haefliger JA, Ahn KH, Lee CH, Manning BD, Sinclair DA, Chen CS, Ozaki CK and Mitchell JR. Amino Acid Restriction Triggers Angiogenesis via GCN2/ATF4 Regulation of VEGF and $\mathrm{H}(2)$ S Production. Cell. 2018;173:117-129.e14.

5. Kanagy NL, Szabo C and Papapetropoulos A. Vascular biology of hydrogen sulfide. Am J Physiol Cell Physiol. 2017;312:C537-C549.

6. Yang G, Wu L, Jiang B, Yang W, Qi J, Cao K, Meng Q, Mustafa AK, Mu W, Zhang S, Snyder $\mathrm{SH}$ and Wang R. H2S as a physiologic vasorelaxant: hypertension in mice with deletion of cystathionine gamma-lyase. Science (New York, NY). 2008;322:587-90.

7. Ahmad A, Olah G, Szczesny B, Wood ME, Whiteman M and Szabo C. AP39, A Mitochondrially Targeted Hydrogen Sulfide Donor, Exerts Protective Effects in Renal Epithelial Cells Subjected to Oxidative Stress in Vitro and in Acute Renal Injury in Vivo. Shock. 2016;45:88-97.

8. Olson KR, Whitfield NL, Bearden SE, St Leger J, Nilson E, Gao Y and Madden JA. Hypoxic pulmonary vasodilation: a paradigm shift with a hydrogen sulfide mechanism. Am J Physiol Regul Integr Comp Physiol. 2010;298:R51-60.

9. Olson KR and Whitfield NL. Hydrogen sulfide and oxygen sensing in the cardiovascular system. Antioxid Redox Signal. 2010;12:1219-34.

10. Zanardo RC, Brancaleone V, Distrutti E, Fiorucci S, Cirino G and Wallace JL. Hydrogen sulfide is an endogenous modulator of leukocyte-mediated inflammation. FASEB J. 2006;20:2118-20.

11. Szabo C. Hydrogen sulphide and its therapeutic potential. Nat Rev Drug Discov. 2007;6:917-35. 
medRxiv preprint doi: https://doi.org/10.1101/2021.02.16.21251804; this version posted February $23,2021$. The copyright holder for this preprint (which was not certified by peer review) is the author/funder, who has granted medRxiv a license to display the preprint in perpetuity. It is made available under a CC-BY-NC-ND 4.0 International license .

12. Mani S, Li H, Untereiner A, Wu L, Yang G, Austin RC, Dickhout JG, Lhotak S, Meng QH and Wang R. Decreased endogenous production of hydrogen sulfide accelerates atherosclerosis. Circulation. 2013;127:2523-34.

13. Zhao ZZ, Wang Z, Li GH, Wang R, Tan JM, Cao X, Suo R and Jiang ZS. Hydrogen sulfide inhibits macrophage-derived foam cell formation. Exp Biol Med (Maywood). 2011;236:169-76.

14. Wang Y, Zhao X, Jin H, Wei H, Li W, Bu D, Tang X, Ren Y, Tang C and Du J. Role of hydrogen sulfide in the development of atherosclerotic lesions in apolipoprotein $\mathrm{E}$ knockout mice. Arterioscler Thromb Vasc Biol. 2009;29:173-9.

15. Potor L, Nagy P, Méhes G, Hendrik Z, Jeney V, Pethő D, Vasas A, Pálinkás Z, Balogh E, Gyetvai Á, Whiteman M, Torregrossa R, Wood ME, Olvasztó S, Nagy P, Balla G and Balla J. Hydrogen Sulfide Abrogates Hemoglobin-Lipid Interaction in Atherosclerotic Lesion. Oxidative Medicine and Cellular Longevity. 2018;2018:3812568.

16. Kondo K, Bhushan S, King AL, Prabhu SD, Hamid T, Koenig S, Murohara T, Predmore BL, Gojon G, Sr., Gojon G, Jr., Wang R, Karusula N, Nicholson CK, Calvert JW and Lefer DJ. H(2)S protects against pressure overload-induced heart failure via upregulation of endothelial nitric oxide synthase. Circulation. 2013;127:1116-27.

17. Wang K, Ahmad S, Cai M, Rennie J, Fujisawa T, Crispi F, Baily J, Miller MR, Cudmore M, Hadoke PW, Wang R, Gratacos E, Buhimschi IA, Buhimschi CS and Ahmed A. Dysregulation of hydrogen sulfide producing enzyme cystathionine gamma-lyase contributes to maternal hypertension and placental abnormalities in preeclampsia. Circulation. 2013;127:2514-22.

18. Fiorucci S, Antonelli E, Mencarelli A, Orlandi S, Renga B, Rizzo G, Distrutti E, Shah V and Morelli $A$. The third gas: $H 2 S$ regulates perfusion pressure in both the isolated and perfused normal rat liver and in cirrhosis. Hepatology. 2005;42:539-48.

19. Candela J, Wang R and White C. Microvascular Endothelial Dysfunction in Obesity Is Driven by Macrophage-Dependent Hydrogen Sulfide Depletion. Arterioscler Thromb Vasc Biol. 2017;37:889-899. 20. Nagy P, Pálinkás Z, Nagy A, Budai B, Tóth I and Vasas A. Chemical aspects of hydrogen sulfide measurements in physiological samples. Biochimica et biophysica acta. 2014;1840:876-91. 21. Ditrói T, Nagy A, Martinelli D, Rosta A, Kožich V and Nagy P. Comprehensive analysis of how experimental parameters affect $\mathrm{H}(2) \mathrm{S}$ measurements by the monobromobimane method. Free radical biology \& medicine. 2019;136:146-158.

22. Hine $C$ and Mitchell JR. Endpoint or Kinetic Measurement of Hydrogen Sulfide Production Capacity in Tissue Extracts. Bio Protoc. 2017;7.

23. Kožich V, Ditrói T, Sokolová J, Kř́žková M, Krijt J, Ješina P and Nagy P. Metabolism of sulfur compounds in homocystinurias. British journal of pharmacology. 2019;176:594-606.

24. Krijt J, Kopecká J, Hnízda A, Moat S, Kluijtmans LA, Mayne P and Kožich V. Determination of cystathionine beta-synthase activity in human plasma by LC-MS/MS: potential use in diagnosis of CBS deficiency. Journal of inherited metabolic disease. 2011;34:49-55.

25. Yang J, Minkler P, Grove D, Wang R, Willard B, Dweik R and Hine C. Non-enzymatic hydrogen sulfide production from cysteine in blood is catalyzed by iron and vitamin B6. Communications Biology. 2019;2.

26. Singh S, Padovani D, Leslie RA, Chiku T and Banerjee R. Relative contributions of cystathionine beta-synthase and gamma-cystathionase to $\mathrm{H} 2 \mathrm{~S}$ biogenesis via alternative transsulfuration reactions. The Journal of biological chemistry. 2009;284:22457-66.

27. Akaike T, Ida T, Wei FY, Nishida M, Kumagai Y, Alam MM, Ihara H, Sawa T, Matsunaga T, Kasamatsu S, Nishimura A, Morita M, Tomizawa K, Nishimura A, Watanabe S, Inaba K, Shima H, Tanuma N, Jung M, Fujii S, Watanabe Y, Ohmuraya M, Nagy P, Feelisch M, Fukuto JM and Motohashi $\mathrm{H}$. Cysteinyl-tRNA synthetase governs cysteine polysulfidation and mitochondrial bioenergetics. Nature communications. 2017;8:1177.

28. Shibuya N, Tanaka M, Yoshida M, Ogasawara Y, Togawa T, Ishii K and Kimura H. 3Mercaptopyruvate sulfurtransferase produces hydrogen sulfide and bound sulfane sulfur in the brain. Antioxidants \& redox signaling. 2009;11:703-14. 
medRxiv preprint doi: https://doi.org/10.1101/2021.02.16.21251804; this version posted February 23, 2021. The copyright holder for this preprint (which was not certified by peer review) is the author/funder, who has granted medRxiv a license to display the preprint in perpetuity. It is made available under a CC-BY-NC-ND 4.0 International license.

29. Beard RS, Jr. and Bearden SE. Vascular complications of cystathionine beta-synthase deficiency: future directions for homocysteine-to-hydrogen sulfide research. Am J Physiol Heart Circ Physiol. 2011;300:H13-26.

30. Nakano S, Ishii I, Shinmura K, Tamaki K, Hishiki T, Akahoshi N, Ida T, Nakanishi T, Kamata S, Kumagai Y, Akaike T, Fukuda K, Sano M and Suematsu M. Hyperhomocysteinemia abrogates fastinginduced cardioprotection against ischemia/reperfusion by limiting bioavailability of hydrogen sulfide anions. J Mol Med (Berl). 2015;93:879-89.

31. Glowacki R, Stachniuk J, Borowczyk K and Jakubowski H. Quantification of homocysteine and cysteine by derivatization with pyridoxal 5'-phosphate and hydrophilic interaction liquid chromatography. Anal Bioanal Chem. 2016;408:1935-41. 
A

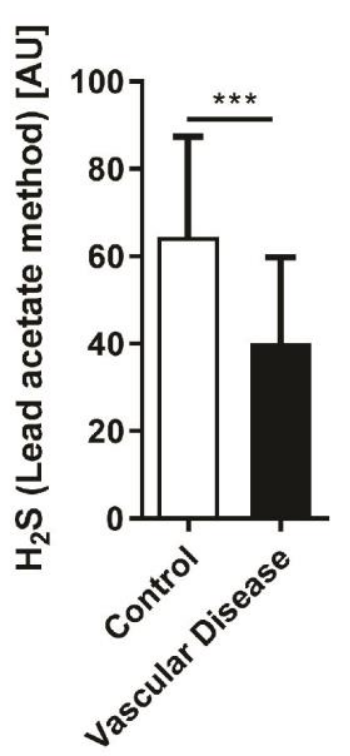

B

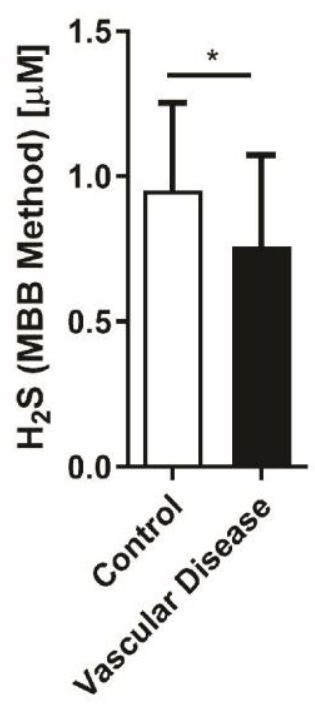

D

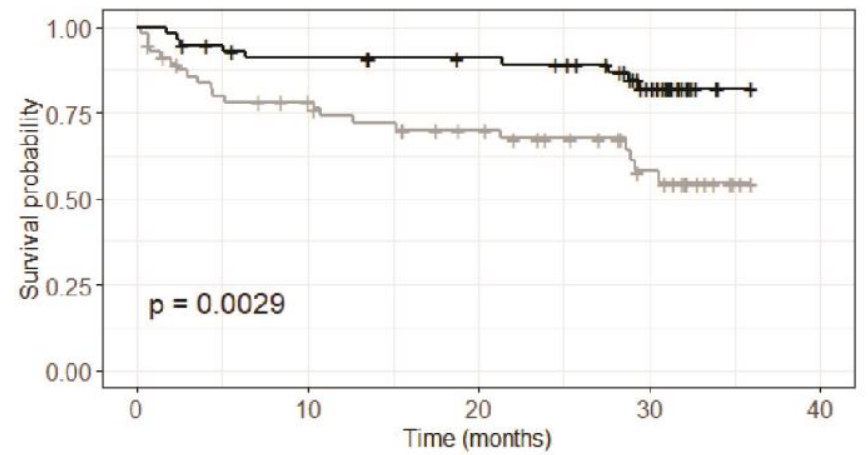

Number at risk

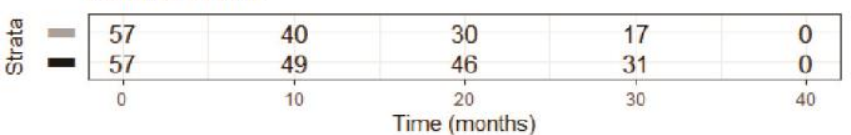

C

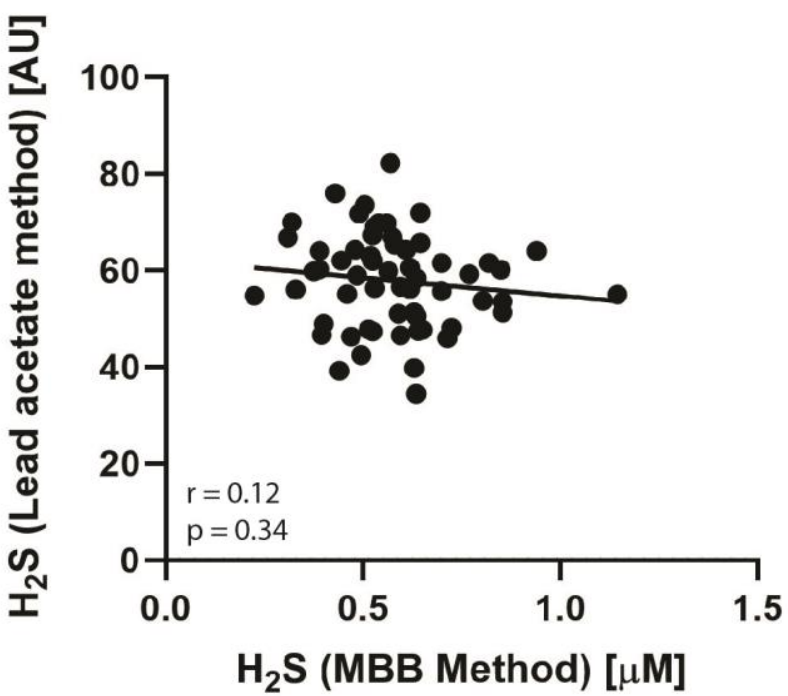

$\mathrm{E}$

Strata + Low Sulfide + High Sulfide

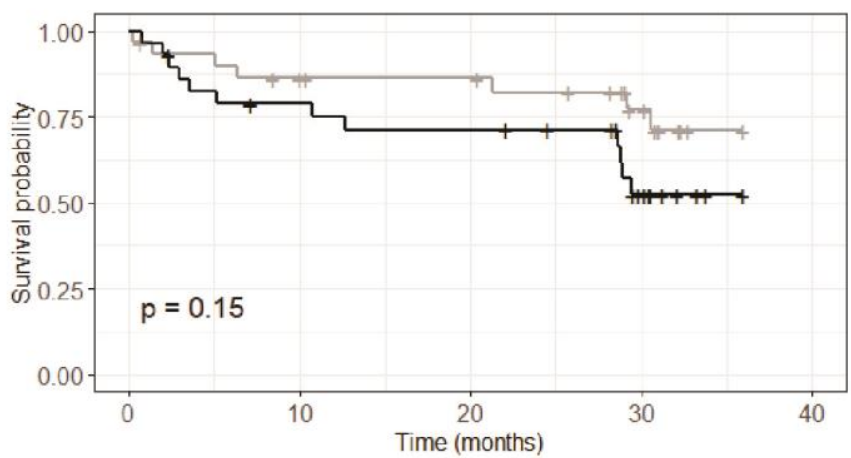

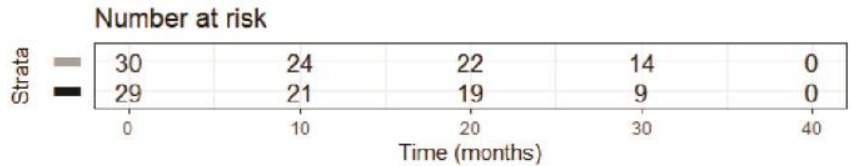

Figure 1. Plasma $\mathrm{H}_{2} \mathrm{~S}$ production capacity and sulfide levels are reduced in patients with vascular disease, with production capacity predicting mortality

(A) Plasma $\mathrm{H}_{2} \mathrm{~S}$ production capacity and (B) plasma sulfide measured by the MBB method from human patients suffering vascular occlusive disease $(n=115)$ and healthy age-matched individuals $(n=20)$. Error bars indicate SD; ${ }^{*} p<0.05,{ }^{* * *} p<0.001$. (C) Correlation between $\mathrm{H}_{2} \mathrm{~S}$ production capacity and sulfide measured by the MBB method in vascular disease patients. (D) Probability of survival for vascular disease patients during follow up after intervention with low $(n=57)$ versus high $(n=57) \mathrm{H}_{2} \mathrm{~S}$ production capacity and (E) low and high plasma sulfide measurements. High versus low was determined by median split. $P$ value calculated from log-rank test. 
medRxiv preprint doi: https://doi.org/10.1101/2021.02.16.21251804; this version posted February 23, 2021. The copyright holder for this preprint (which was not certified by peer review) is the author/funder, who has granted medRxiv a license to display the preprint in perpetuity.

It is made available under a CC-BY-NC-ND 4.0 International license.

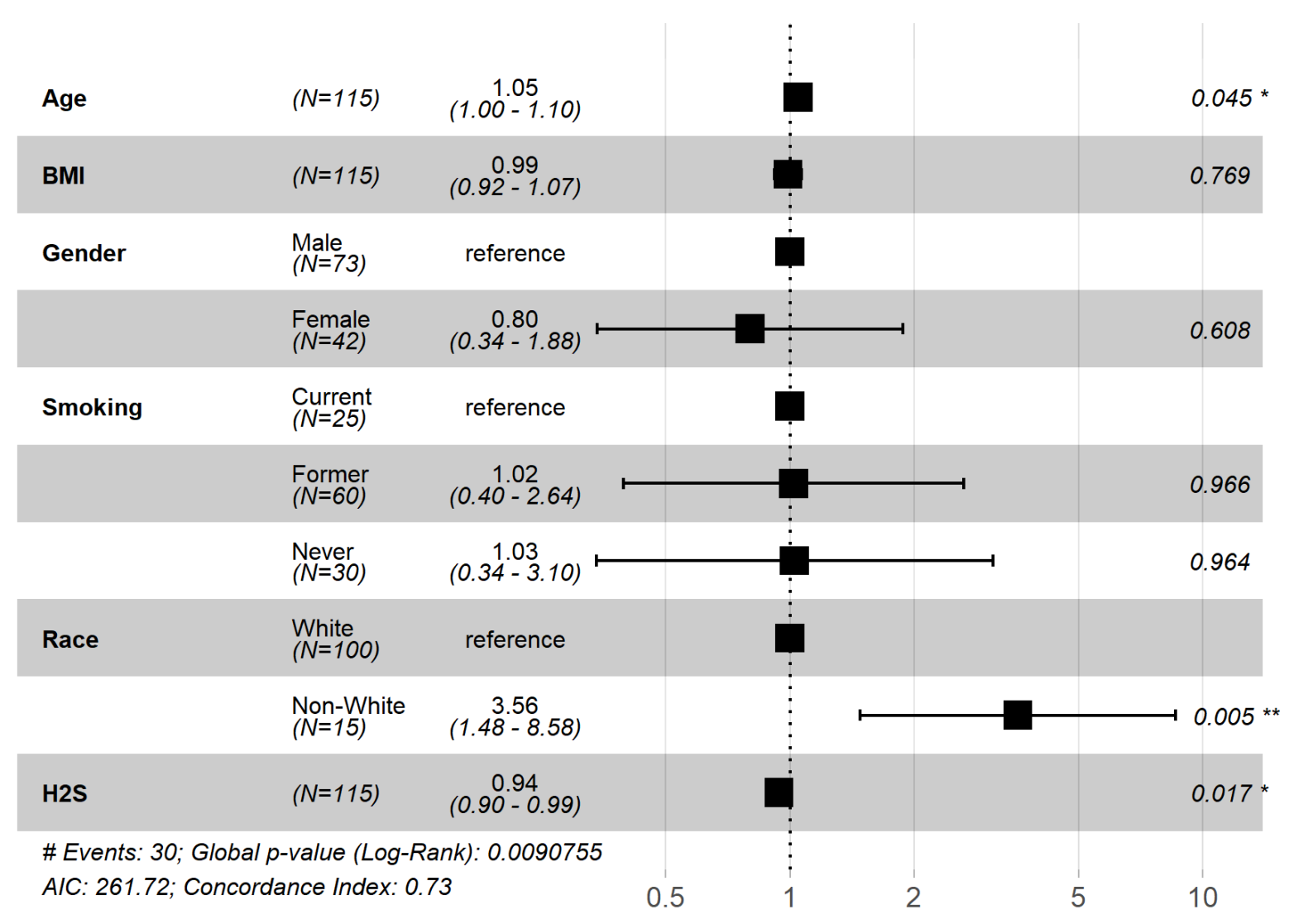

Figure 2. Hazard ratios of death during follow up period

Hazard ratio estimates and $95 \%$ confidence intervals for clinically relevant parameters and plasma $\mathrm{H}_{2} \mathrm{~S}$ production capacity as measured by the lead acetate release method 

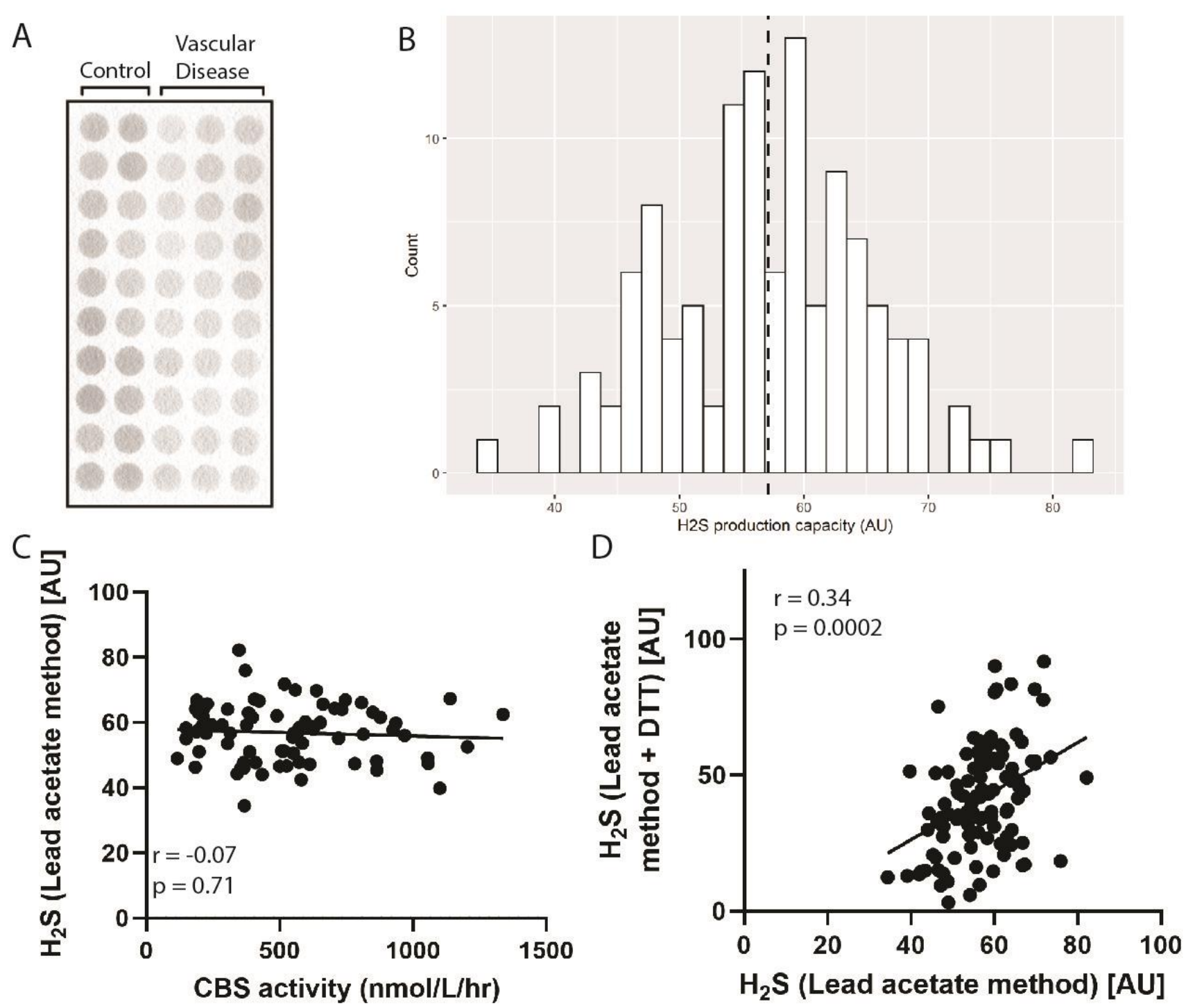

E

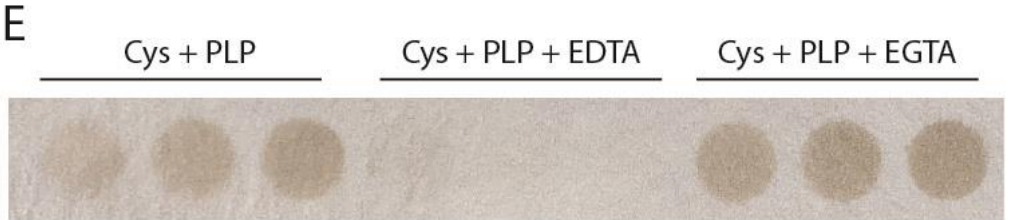

Figure S1. Plasma $\mathrm{H}_{2} \mathrm{~S}$ production capacity occurs by a non-enzymatic, iron-dependent process. (A) Image of $\mathrm{H}_{2} \mathrm{~S}$ released from plasma onto lead acetate paper. (B) Histogram of quantified lead acetate $\mathrm{H}_{2} \mathrm{~S}$ release from healthy and diseased individuals. (C) Correlation between plasma $\mathrm{H}_{2} \mathrm{~S}$ production capacity and plasma cystathionine beta synthase protein activity. (D)Correlation between plasma $\mathrm{H}_{2} \mathrm{~S}$ production capacity and plasma $\mathrm{H}_{2} \mathrm{~S}$ production capacity under denaturing conditions with DTT. (E) Plasma $\mathrm{H}_{2} \mathrm{~S}$ production capacity under normal assay conditions (cysteine plus PLP added), or with added EDTA (12.5mM) or EGTA $(12.5 \mathrm{mM}$ 
Supplemental Table 1: Baseline Study Population Characteristics

\begin{tabular}{|c|c|c|}
\hline Variable & Control Cohort $n=20$ & Vascular Cohort $n=115$ \\
\hline Age (SD) & $68(2.3)$ & $69(9)$ \\
\hline Male (\%) & $13(65)$ & $73(63)$ \\
\hline \multicolumn{3}{|l|}{ Ethnicity (\%) } \\
\hline White & $18(90)$ & $97(84)$ \\
\hline Hispanic & 0 & $10(9)$ \\
\hline Black & 0 & $4(3.5)$ \\
\hline Other & $2(10)$ & $4(3.5)$ \\
\hline $\mathrm{BMI}(\mathrm{SD})$ & $28.7(7.2)$ & $28.3(5.3)$ \\
\hline \multicolumn{3}{|l|}{ Comorbidities (\%) } \\
\hline Heart failure & 0 & $19(17)$ \\
\hline History of stroke & 0 & $24(21)$ \\
\hline PAD & 0 & $75(65)$ \\
\hline Prior coronary intervention & 0 & $44(38)$ \\
\hline Prior MI & 0 & $30(26)$ \\
\hline Hypertension & $19(95)$ & $106(92)$ \\
\hline Hyperlipidemia & $6(30)$ & $98(85)$ \\
\hline COPD & 0 & $7(6)$ \\
\hline Renal dysfunction & $5(1)$ & $16(14)$ \\
\hline Diabetes mellitus & $2(10)$ & $45(39)$ \\
\hline \multicolumn{3}{|l|}{ Smoking status (\%) } \\
\hline Never & $9(45)$ & $25(22)$ \\
\hline Former & $11(55)$ & $60(52)$ \\
\hline Current & 0 & $30(26)$ \\
\hline Renal dysfunction & $5(1)$ & $16(14)$ \\
\hline Diabetes mellitus & $2(10)$ & $45(39)$ \\
\hline \multicolumn{3}{|l|}{ Procedure type (\%) } \\
\hline Carotid endarterectomy & 0 & $49(43)$ \\
\hline Infraguinal revascularization & 0 & $44(38)$ \\
\hline Lower extremity amputation & 0 & $22(19)$ \\
\hline
\end{tabular}

SD, standard deviation; BMI, body mass index; MI, myocardial infarct; HTN, hypertension; COPD, chronic obstructive pulmonary disease 